\title{
KUALITAS KELEKATAN ANAK DENGAN PENGASUH DI LEMBAGA KESEJAHTERAAN SOSIAL ANAK (LKSA) AL-KAUTSAR LEMBANG KABUPATEN BANDUNG BARAT
}

\author{
Mu'alimatus Sholihah, Denti Kardeti, dan Meiti Subardhini \\ Politeknik Kesejahteraan Sosial Bandung \\ Email: mualimatuss@gmail.com
}

\begin{abstract}
Attachment refers to a relationship or emotional bonding that last for a long time, intertwined between individuals and attachment figures that are characterized by a desire to seek and maintain closeness to the attachment figures, especially in pressure time. This research aims to gain the empirical description about warmth of children to caregivers. The method in this research uses descriptive method with a quantitative approach. Sampling in this research is census, and data collection technique uses: 1) questionnaire, 2) interview, 3) observation, and 4) documentation study. As for the measuring instrument validity test uses face validity. Furthermore, the result analysed through quantitative and qualitative analysis. The result shows that the attachment quality of children to caregivers in AlKautsar's Children Welfare Institution Lembang, West Bandung Regency is in moderate category. Therefore, it is necessary to make an improvement throught the proposed program which is EDUFAS (Education and Fun Sharing) "Improvement of The Attachment Quality of Children to Caregivers in Al-Kautsar's Children Welfare Institution Lembang, West Bandung Regency".
\end{abstract}

Keywords: Attachment, Children, Caregivers.

Abstrak. Kualitas kelekatan (attachment) merujuk pada ikatan emosional yang bertahan dalam waktu yang lama, terjalin antara individu dengan figur lekatnya yang ditandai adanya keinginan untuk mencari dan memelihara kedekatan dengan figur lekat tersebut terutama pada saat-saat yang menekan. Penelitian ini bertujuan untuk mendapatkan gambaran empiris tentang kehangatan (warmth) anak dengan pengasuh. Metode penelitian yang digunakan dalam penelitian adalah metode kuantitatif dengan pendekatan deskriptif. Teknik penarikan sampel dalam penelitian ini adalah sensus, yaitu dengan jumlah responden sebanyak 38 anak. Teknik pengumpulan data yang digunakan adalah: 1) kuesioner, 2) wawancara tidak terstruktur, 3) observasi, dan 4) studi dokumentasi. Adapun uji validitas alat ukur menggunakan validitas muka (face validity). Selanjutnya hasil penelitian dianalisis menggunakan analisis kuantitatif dan kualitatif. Hasil penelitian menunjukkan bahwa kualitas kelekatan anak dengan pengasuh di Lembaga Kesejahteraan Sosial Anak Al-Kautsar Lembang Kabupaten Bandung Barat termasuk dalam kategori sedang. Begitu pula pada semua aspek dalam kualitas kelekatan termasuk dalam kategori sedang. Maka dari itu diperlukan upaya peningkatan melalui program yang diusulkan yaitu EDUFAS (Educating and Fun Sharing) "Peningkatan Kualitas Kelekatan Anak dengan Pengasuh di Lembaga Kesejahteraan Sosial Anak (LKSA) Al-Kautsar Lembang Kabupaten Bandung Barat".

Kata Kunci: Kelekatan, Anak, Pengasuh. 
- Mu'alimatus Sholihah, Denti Kardeti, dan Meiti Subardhini

\section{Pendahuluan}

Anak merupakan cita-cita perjuangan bangsa sekaligus sebagai sumber daya manusia di masa depan yang menentukan generasi mendatang. Desmita (2013) mengatakan bahwa masa anak merupakan masa yang terpanjang dalam rentang kehidupan saat di mana individu relatif tidak berdaya dan bergantung pada orang lain. Anak bukan orang dewasa dalam ukuran mini karena anak memiliki taraf dan pencapaian perkembangan tersendiri, sehingga anak harus memperoleh perlakuan yang tepat sesuai dengan perkembangannya (Soetjiningsih, 2012). Kualitas perkembangan dan pertumbuhan anak yang baik akan menentukan masa depan yang baik pula untuk anak (Lestari, 2016). Sayangnya, tidak semua anak mempunyai kesempatan yang sama, banyak di antara mereka yang beresiko tinggi untuk tidak tumbuh dan berkembang secara sehat. Anak-anak tersebut juga tidak terpenuhi kebutuhan mereka secara utuh, seperti halnya kebutuhan akan nutrisi yang tepat, pendidikan yang terbaik, serta kasih sayang yang cukup dan juga kebutuhan akan kelekatan (Huraerah, 2012).

Kelekatan menurut Soetjiningsih (2012:154) adalah "kecenderungan dan keinginan seseorang untuk mencari kedekatan dengan orang lain dan mencari kepuasan dalam hubungan dengan orang lain tersebut." Sedangkan kelekatan menurut Bowlby dalam Geldard, K. \& David, G. (2011:31) yaitu:

Bahwa kelekatan atau kemelakatan adalah ikatan afeksional kekal yang memiliki suatu biologis vital yang sangat dibutuhkan untuk bertahan hidup dan bahwa hubungan antara seorang anak dan figur kemelakatannya menyediakan suatu fondasi kokoh yang akan digunakannya untuk mengeksplorasi dan menguasai dunia.

Bowlby menyebut kelekatan terbagi ke dalam tiga pola yaitu secure attachment (aman), resistant attachment (cemas) dan avoidant attachment (menghindar). Anak dengan secure attachment akan percaya diri, optimis, serta mampu membina hubungan dekat dengan orang lain, sedangkan dengan pola kelekatan yang lain, anak akan kesulitan untuk percaya diri dan tidak mampu berhubungan dengan orang lain. Menurut Chen dalam Lestari (2016), kualitas kelekatan yang terjalin antara anak dengan figur lekat dapat diukur dengan beberapa aspek yaitu kehangatan (warmth), rasa aman (secure), kepercayaan (trust), afeksi positif (positive affect), dan ketanggapan (responsiveness). Kelekatan bisa didapatkan anak dari lingkungan keluarga, terutama dari kedua 
orang tua mereka. Lestari (2016) mengatakan bahwa keluarga merupakan unsur yang amat penting bagi seorang anak, terutama kedua orangtua sebagai figur utama dan role model bagi mereka. Hubungan yang terjalin antara anak dengan orangtua menjadi suatu hal yang penting karena merupakan sumber emosional dan kognitif bagi anak.

Namun kenyataannya, beberapa anak dihadapkan pada kenyataan yang sulit bahwa dirinya harus berpisah dengan keluarga karena suatu alasan. Sehingga mereka menjadi anak yatim, piatu, atau yatim piatu, dan mayoritas disebabkan karena ketidakmampuan keluarga dalam memenuhi kebutuhan jasmani, rohani maupun sosial anak (Oktyanti, 2017).

Pemerintah melalui Kementerian Sosial menyediakan sarana untuk menampung anak-anak tersebut, yaitu pengasuhan di Lembaga Kesejahteraan Sosial Anak (LKSA) yang berperan membesarkan, mengasuh, mendidik dan memenuhi kebutuhan-kebutuhan anak termasuk kebutuhan kelekatan. LKSA menjadi pilihan terakhir sebagai sarana pelayanan pengasuhan alternatif untuk anak yang tidak bisa diasuh di dalam keluarga inti, keluarga besar, kerabat, atau keluarga pengganti. Menurut data Badan Pusat Statistika (BPS) Provinsi Jawa Barat pada tahun 2016, jumlah anak terlantar sebanyak 135.757, sedangkan di Kabupaten Bandung Barat sendiri sebanyak 2.842 anak. Berdasarkan data dari Dinas Sosial Kabupaten Bandung Barat, pada tahun 2017, terdapat 1.024 anak asuh yang tinggal di dalam LKSA yang tersebar di seluruh wilayah Kabupaten Bandung Barat. Apabila melihat data tersebut maka jumlah anak terlantar cukup besar.

Menurut Peraturan Menteri Sosial Nomor 30 Tahun 2011 tentang Standar Nasional Pengasuhan Anak (SNPA) untuk LKSA, anak-anak yang tinggal di LKSA, diasuh oleh pengasuh yang merupakan pengganti figur orangtua. Figur lekat anak akan bergeser kepada pengasuh di LKSA, sebab orang yang paling banyak mengasuh dan dekat dengan keseharian anak adalah pengasuh. Rasa aman dan nyaman yang berasal dari kualitas kelekatan yang terjalin, masih bisa anak-anak dapatkan dari pengasuh panti (Ervika, 2005). Kelekatan dapat berkembang sesuai dengan perasaan dan perilaku anak dalam kehidupannya. Anak pada awalnya memiliki figur lekat satu orang biasanya adalah ibu, dan seiring dengan bertambahnya usia anak maka figur lekatnya bertambah dengan orang-orang tertentu yang dekat dengan kehidupannya (Soetjiningsih, 2012).

Pengasuh harus mampu menciptakan kelekatan yang aman (secure 
attachment) kepada anak-anak asuh di LKSA, termasuk anak asuh yang dari usia bayi sudah tinggal di dalam LKSA. Anak asuh yang dari usia bayi sudah berada di LKSA tidak pernah mengetahui siapa kedua orangtuanya. Pengasuh diharapkan mampu menjadi figur lekat dengan memberikan kasih sayang, dukungan emosional dan menjadi sumber pemberi rasa aman bagi anak, agar terbangun kualitas kelekatan yang baik (Ervika, 2005). Tujuan pengasuhan melalui LKSA adalah diprioritaskan untuk menyediakan lingkungan yang dapat memenuhi kebutuhan kasih sayang, kelekatan (attachment), dan permanensi melalui keluarga pengganti (Permensos, Nomor 30 tahun 2011). Maka dari itu, untuk mewujudkan tujuan dari pengasuhan melalui LKSA, dihadirkan sosok pengasuh di dalam LKSA. Namun kenyataannya, masih banyak Lembaga Kesejahteraan Sosial Anak yang tidak memenuhi standar dalam hal pemenuhan akan sosok pengasuh di dalam LKSA.

Lembaga Kesejahteraan Sosial Anak Al-Kautsar yang berlokasi di Jalan Mutiara Utama No. 176 RT 04 RW 05, Desa Lembang, Kecamatan Lembang, Kabupaten Bandung Barat merupakan salah satu sistem pengasuhan alternatif yang memberikan pelayanan pengasuhan kepada anak. LKSA ini dipilih oleh peneliti dengan alasan karena ditemukan beberapa masalah yang berkaitan dengan kualitas hubungan kelekatan antara anak dan pengasuh. Salah satu pengurus LKSA Al Kautsar menuturkan bahwa LSKA ini hanya memiliki 4 pengasuh dan 9 pengurus. Mereka tidak semuanya bermukim menetap di LKSA. Hanya satu orang pengasuh dan satu orang lagi pengurus yang tinggal menetap. Hal itu menyebabkan pengasuh tidak dapat mengawasi dan menjalin kedekatan dengan anak selama dua puluh empat jam. Pengasuh juga merangkap tugas lainnya di LKSA sehingga fokus perhatiannya terbagi-bagi.

Jumlah anak asuh di LKSA Al Kautsar berjumlah 58 anak dengan rentang usia 4-18 tahun. Mereka dengan latar belakang berbeda-beda: anak yatim, piatu, yatim piatu dan dhuafa. Jumlah pengasuh yang hanya 4 orang harus memberikan pengasuhan terhadap anak yang terlampau banyak, akibatnya tidak semua anak asuh mendapatkan perhatian secara optimal (individual). Padahal Peraturan Menteri Sosial Nomor 30 Tahun 2011 tentang Standar Nasional Pengasuhan Anak untuk LKSA menyebutkan bahwa setiap anak harus memiliki satu pengasuh tetap yang dapat ditemui anak setiap saat dan memberikan perhatian secara individual. Maka dari itu, kondisi tersebut tidak memenuhi standar yang seharusnya dan mempengaruhi kualitas hubungan yang terjalin di antara 
anak dan pengasuh, karena hubungan tersebut merupakan kunci terciptanya kelekatan di antara keduanya.

Menurut penuturan beberapa anak asuh di LKSA Al Kautsar, kondisi yang sering dikeluhkan oleh mereka yaitu perihal peraturan (tata tertib) yang diterapkan di LKSA bisa dikatakan sangat ketat. Walaupun itu semua demi kebaikan dan kepentingan terbaik anak, namun untuk beberapa anak, hal tersebut membuat mereka cenderung tidak terbuka dan merasa takut kepada pengasuh. Selain itu, anak-anak asuh di sana mempunyai kegiatan yang padat, dari kegiatan sekolah beserta ekstrakulikulernya yang mengharuskan mereka pulang ke panti sore hari. Kondisi tersebut menyebabkan intensitas pertemuan antara anak dan pengasuh menjadi sedikit, komunikasi serta interaksi yang ada juga menjadi terbatas, dan akhirnya kualitas kelekatan antara anak dan pengasuh menjadi berkurang. Padahal menurut Bowlby dalam Farrington (2005), kelekatan (attachment) aman yang diperoleh anak merupakan fondasi untuk terbentuknya kemandirian dan membimbing anak dalam berhubungan dengan orang lain di masa depan.

Adapun tujuan penelitian ini adalah untuk mengetahui gambaran kualitas kelekatan yang terjadi antara anak dengan pengasuh dilihat dari aspek kehangatan di Lembaga Kesejahteraan Sosial Anak Al Kautsar Lembang Kabupaten Bandung Barat.

\section{Metode}

Metode penelitian yang digunakan dalam penelitian ini adalah metode kuantitatif dengan pendekatan deskriptif. Populasi dalam penelitian ini adalah keseluruhan anak asuh penghuni Lembaga Kesejahteraan Sosial Anak Al Kautsar Lembang Kabupaten Bandung Barat, yaitu sebanyak 38 anak, berusia 12-17 tahun. Penulis menetapkan populasi tersebut dengan pertimbangan teori John Piaget tentang Tahap-Tahap Perkembangan Kognitif. Menurut John Piaget dalam Suparno (2001), anak dengan rentang usia 12-17 tahun termasuk dalam Tahap Operasional Formal, yaitu tahap di mana anak sudah mampu berpikir secara abstrak dan logis. Anak sudah mampu menarik kesimpulan tentang suatu hal serta memberikan penafsiran dan mengembangkan hipotesa yang ada. Maka dari itu, anak asuh dengan rentang usia tersebut diharapkan sudah mampu memberikan penilaian dan pertimbangan tentang bagaimana kualitas kelekatan di antara dirinya dan pengasuhnya. Sedangkan untuk teknik penarikan 
sampel yang digunakan yaitu sampling jenuh (sensus). Teknik sampling jenuh (sensus) digunakan karena jumlah populasinya hanya sebanyak 38 responden yang sudah memenuhi syarat, maka dari itu sampel yang digunakan dalam penelitian ini adalah mengambil keseluruhan dari banyaknya populasi tersebut.

Teknik pengumpulan data yang digunakan adalah kuesioner (angket), wawancara tidak terstruktur, observasi non partisipatif dan studi dokumentasi. Penelitian ini menggunakan skala pengukuran yaitu skala likert. Kemudian Uji validitas yang digunakan adalah validitas muka (Face Validity). Selanjutnya uji reliabilitas dengan perhitungan Alpha Cronbach, dan dilakukan dengan menggunakan aplikasi SPSS 22.0 menunjukkan alpha sebesar 0.973. Teknik analisis data yang digunakan dalam penelitian kuantitatif ini adalah statistik deskriptif. Analisis data terdiri dari tahapan editing, mengkodekan data, membuat tabulasi, perhitungan, interpretasi data dan penarikan kesimpulan.

\section{Hasil dan Diskusi}

Kehangatan (warmth) didefinisikan sebagai bentuk keterlibatan orang tua atau pengganti figur orang tua dalam aktivitas anak, kepedulian dan perhatian serta penghargaan dan antusiasme terhadap tingkah laku positif yang ditampilkan oleh anak. Aspek ini terdiri dari 10 (sepuluh) item pernyataan, berikut adalah rekapitulasi hasil penelitian dari setiap item pernyataannya, yaitu:

Tabel 3.1 Rekapitulasi Aspek Kehangatan (Warmth)

Anak dengan Pengasuh

\begin{tabular}{|c|l|c|c|c|c|}
\hline No. & \multicolumn{1}{|c|}{ Pernyataan } & $\begin{array}{c}\text { Skor } \\
\text { Aktual }\end{array}$ & $\begin{array}{c}\text { Skor } \\
\text { Ideal }\end{array}$ & $\begin{array}{c}\text { Persentase } \\
\mathbf{( \% )}\end{array}$ & $\begin{array}{c}\text { Kategori } \\
\text { Skor }\end{array}$ \\
\hline 1. & $\begin{array}{l}\text { Pengasuh memberikan ucapan } \\
\text { selamat apabila saya mampu ber- } \\
\text { prestasi di sekolah. }\end{array}$ & 118 & 152 & 77.63 & Tinggi \\
\hline 2. & $\begin{array}{l}\text { Pengasuh menyemangati saya keti- } \\
\text { ka saya menghadapi ujian. }\end{array}$ & 122 & 152 & 80.26 & Tinggi \\
\hline 3. & $\begin{array}{l}\text { Pengasuh meluangkan waktu un- } \\
\text { tuk menemani saya belajar. }\end{array}$ & 91 & 152 & 59.87 & Sedang \\
\hline 4. & $\begin{array}{l}\text { Pengasuh selalu menanyakan } \\
\text { kabar saya. }\end{array}$ & 98 & 152 & 64.47 & Sedang \\
\hline 5. & $\begin{array}{l}\text { Pengasuh memuji saya, apabila } \\
\text { saya melakukan sikap positif. }\end{array}$ & 110 & 152 & 72.37 & Sedang \\
\hline
\end{tabular}


Mu'alimatus Sholihah, Denti Kardeti, dan Meiti Subardhini

\begin{tabular}{|c|l|c|c|c|c|}
\hline 6. & $\begin{array}{l}\text { Pengasuh selalu mengingatkan } \\
\text { saya untuk melaksanakan sholat. }\end{array}$ & 131 & 152 & 86.18 & Tinggi \\
\hline 7. & $\begin{array}{l}\text { Pengasuh tidak pernah menyem- } \\
\text { patkan mengobrol dengan saya. }\end{array}$ & 104 & 152 & 68.42 & Sedang \\
\hline 8. & $\begin{array}{l}\text { Pengasuh tidak pernah menemani } \\
\text { saya makan. }\end{array}$ & 101 & 152 & 66.44 & Sedang \\
\hline 9. & $\begin{array}{l}\text { Pengasuh tidak pernah mengin- } \\
\text { gatkan saya untuk mengerjakan } \\
\text { tugas-dari sekolah. }\end{array}$ & 107 & 152 & 70.39 & Sedang \\
\hline 10. & $\begin{array}{l}\text { Pengasuh tidak pernah memper- } \\
\text { hatikan kebersihan diri saya. }\end{array}$ & 116 & 152 & 76.31 & Tinggi \\
\hline & Jumlah & 1098 & 1520 & 72.23 & Sedang \\
\hline
\end{tabular}

Sumber: Hasil Penelitian Tahun 2019

Berdasarkan hasil rekapitulasi pada aspek kehangatan (warmth) di atas dapat diketahui bahwa jumlah keseluruhan skor aktual yang didapatkan dari aspek kehangatan (warmth) anak dengan pengasuh yaitu 1098. Jumlah skor aktual tersebut akan digunakan dalam menentukan kategori untuk aspek kehangatan (warmth) anak dengan pengasuh pada garis kontinum. Adapun perhitungan untuk menentukan kategori tersebut pada garis kontinum, adalah sebagai berikut:

\section{Gambar 3.1 Rumus Perhitungan Batas Skor \\ Aspek Kehangatan (Warmth)}

Skor maksimum $=$ nilai tertinggi $\mathrm{x}$ jumlah pernyataan

$$
\begin{aligned}
& x \text { jumlah responden } \\
= & 4 \times 10 \times 38 \\
= & 1520
\end{aligned}
$$

Skor minimum $=$ nilai terendah $\mathrm{x}$ jumlah pernyataan

$$
\begin{aligned}
& x \text { jumlah responden } \\
= & 1 \times 10 \times 38 \\
= & 380
\end{aligned}
$$

$$
\begin{aligned}
\mathrm{i} & =\frac{R R}{k k} \\
& =\frac{11401140}{3 \quad 3} \\
& =380380
\end{aligned}
$$

\section{Keterangan:}

$\mathrm{R}=$ Range (rentang)

$\mathrm{i}=$ Interval Kelas

$\mathrm{k}=$ Jumlah Keerval

Range $($ rentang) $=$ skor maksimum - skor minimum

$$
\begin{aligned}
& =1520-380 \\
& =1140
\end{aligned}
$$




\section{Kualitas Kelekatan Anak dengan Pengasuh \\ di Lembaga Kesejahteraan Sosial Anak (LKSA) \\ Al-Kautsar Lembang Kabupaten Bandung Barat}

- Mu'alimatus Sholihah, Denti Kardeti, dan Meiti Subardhini

Sumber : Hasil Penelitian Tahun 2019

$$
\begin{gathered}
\text { Rendah }=380-760 \\
\text { Sedang }=761-1140 \\
\text { Tinggi }=1141-1520
\end{gathered}
$$

Gambar 3.2 Batas Skor Garis Kontinum Aspek Kehangatan (Warmth)

Sumber : Hasil Penelitian Tahun 2019

Selanjutnya, gambaran aspek kehangatan (warmth) anak dengan pengasuh dengan jumlah skor aktual 1098, apabila dilihat pada garis kontinum yaitu sebagai berikut:

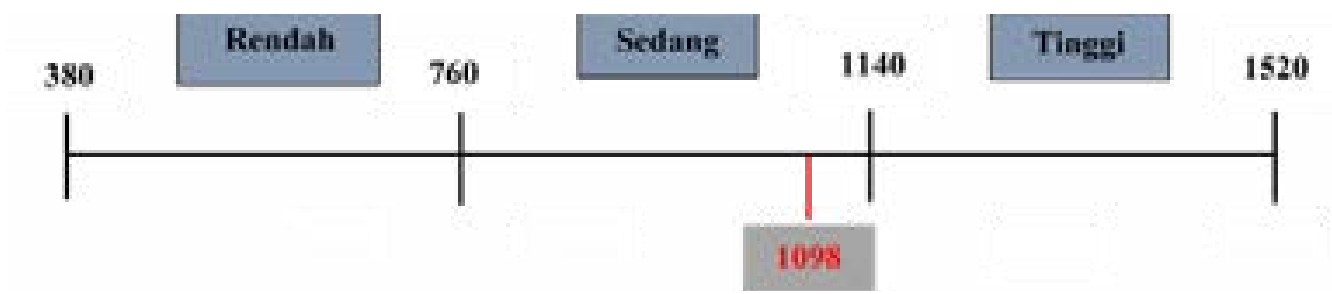

Gambar 3.3 Garis Kontinum Aspek Kehangatan (Warmth) Sumber : Hasil Penelitian Tahun 2019

Gambar 3.3 menunjukkan bahwa kualitas kelekatan anak dengan pengasuh di Lembaga Kesejahteraan Sosial Anak Al Kautsar Lembang Kabupaten Bandung Barat pada aspek kehangatan (warmth), dengan total skor sebesar 1098 termasuk dalam kategori sedang. Sedangkan secara keseluruhan kualitas kelekatan anak dengan pengasuh di Lembaga Kesejahteraan Sosial Anak Al Kautsar Lembang Kabupaten Bandung Barat, termasuk dalam kategori sedang. Kondisi tersebut karena dipengaruhi oleh beberapa faktor seperti halnya masih terdapat unsur penyiksaan dari pengasuh terhadap anak. Penyiksaan tersebut dilakukan baik secara emosional yaitu dengan pengasuh yang masih sering marah-marah kepada anak, serta secara fisik yaitu dengan mencubit maupun memukul walaupun intensitasnya tidak banyak. Sistem Pendidikan yang tradisional yang seringkali menggunakan cara hukuman (baik fisik maupun emosional) untuk mendidik dan mendisiplinkan anak, pengasuh yang bersikap menjaga jarak dan bahkan ada yang sengaja membangun image menakutkan agar anak hormat dan patuh pada mereka. Padahal cara tersebut justru akan membuat anak tumbuh menjadi pribadi yang penakut, mudah berkecil hati dan tidak percaya diri. 
Kemudian faktor lain yang mempengaruhi adalah karena kurang konsistennya cara pengasuhan yang dilakukan oleh pengasuh, sikap pengasuh yang kurang dapat diprediksi seperti halnya pengasuh yang kadangkala bersifat manis, tiba-tiba bisa berubah drastis dengan mudah marah, membuat anak menjadi bingung, tidak yakin dan cukup sulit mempercayai dan patuh pada pengasuh mereka. Kedua faktor tersebut diperkuat dengan hasil wawancara tidak terstruktur kepada responden anak asuh yang menyatakan hal serupa. Erickson dalam Efendi (2010) mengatakan bahwa ada beberapa faktor yang dapat menyebabkan gangguan pada kelekatan, yaitu antara lain adalah adanya penyiksaan secara emosional maupun fisik dan tidak konsistennya cara pengasuhan yang diberikan oleh figur lekat.

Kualitas kelekatan anak dengan pengasuh di Lembaga Kesejahteraan Sosial Anak (LKSA) Al Kautsar berada dalam kategori sedang yang dimaksudkan di sini adalah kecenderungan anak yang kurang yakin bahwa figur lekat yaitu pengasuh mereka akan selalu ada untuk mereka. Karena rasa kurang yakin ini, anak mudah mengalami kecemasan untuk berpisah. Dalam diri anak muncul ketidakpastian, karena pengasuh tidak selalu ada, serta terdapat jarak di antara mereka. Kondisi tersebut terjadi akibat respon atau ketersediaan yang tidak konsisten dari pengasuhnya, kadang ada, kadang tidak, kadang baik, kadang marah-marah. Kualitas kelekatan anak dengan pengasuh di LKSA Al Kautsar dalam kategori sedang cenderung termasuk dalam Pola Resistant Attachment (Ambivalen).

Dalam aspek kehangatan yaitu perilaku hangat yang ditampilkan dalam hubungan kelekatan di antara anak dan pengasuh di LKSA Al Kautsar tercermin dari keikutsertaan pengasuh di dalam aktivitas sehari-hari bersama dengan anak, seperti halnya pengasuh yang meluangkan waktunya untuk sekedar menemani anak makan. Kondisi tersebut sesuai dengan pendapat yang dikemukakan oleh Broderick \& Blewitt dalam Rodriguez, dkk. (2009) bahwa aspek kehangatan menyiratkan tentang keterlibatan dan ketertarikan seseorang dalam aktivitas yang dilakukan oleh anak. Selain itu, aspek kehangatan juga terwujud dari perhatian pengasuh terhadap kebutuhan dan kondisi anak, seperti halnya pengasuh yang selalu mengingatkan anak untuk menunaikan sholat. Kondisi tersebut sesuai dengan pendapat dari Efendi (2010) yang mengatakan bahwa salah satu bentuk dari kehangatan figur lekat adalah dengan perhatian terhadap kesejahteraan anak. Kemudian tergambarkan juga pada penghargaan 


\section{Kualitas Kelekatan Anak dengan Pengasuh \\ di Lembaga Kesejahteraan Sosial Anak (LKSA) \\ Al-Kautsar Lembang Kabupaten Bandung Barat}

- Mu'alimatus Sholihah, Denti Kardeti, dan Meiti Subardhini

yang diberikan pengasuh kepada anak atas perilaku positif yang ditampilkan oleh mereka, misalkan saja pengasuh yang memberikan ucapan selamat atas keberhasilan apabila anak mampu berprestasi di sekolahnya.

Selanjutnya, berdasarkan keseluruhan jawaban responden menggambarkan bahwa kualitas kelekatan yang terjalin antara pengasuh dan anak di LKSA Al Kautsar dalam aspek kehangatan cukup mempunyai hubungan yang hangat. Namun dari jawaban responden juga, menggambarkan bahwa aspek kehangatan dari pengasuh belum merata diberikan kepada seluruh anak asuh yang ada, sehingga sebagian anak mengaku kurang merasakan kehangatan dari sosok pengasuh yang merawat mereka. Maka dari itu diperlukan adanya upaya nyata untuk meningkatkan kualitas kelekatan yang dilihat dari aspek kehangatan, agar lebih maksimal atau agar mencapai skor yang lebih tinggi.

Berdasarkan analisis permasalahan pada aspek kehangatan di atas, berikut analisis kebutuhannya berkaitan dengan kurangnya kualitas kelekatan atau lebih tepatnya kurangnya keterlibatan pengasuh dalam aktivitas yang dilakukan oleh anak serta pengasuh yang kurang mengetahui kegiatan-kegiatan yang diikuti oleh anak di luar LKSA, yang dapat menjadi penyebab munculnya masalah-masalah lainnya. Kebutuhan berkaitan dengan hal tersebut yaitu peningkatan kontrol serta pemantauan dari pengasuh. Menurut Lestari (2016), kontrol dan juga pemantauan merupakan salah satu dimensi pengasuhan yang seharunya ada di dalam hubungan kelekatan antara anak dengan figur orang tua mereka, dalam hal ini digantikan oleh pengasuh.

Kontrol dan pemantauan yang dimaksud di sini adalah dalam pengertian yang positif. Kontrol di sini bisa dengan kontrol secara psikologis atau kontrol secara perilaku. Sedangkan bentuk pemantauan yang bisa diberikan pengasuh adalah dengan terlibat dan memberikan dukungan atas aktivitas-aktivitas yang dilakukan anak. Waizenhofer dalam Lestari (2016) membedakan dua bentuk pemantauan yang diberikan orang tua kepada anak: 1) pemantauan dengan cara menanyakan langsung kepada anak atau ikut berpartisipasi dalam aktivitas anak; dan 2) pemantauan dengan mengetahui aktivitas rutin atau mendapatkan informasi dari orang lain tanpa menanyakan kenapa anak secara langsung. Pemantauan dari pengasuh di LKSA Al Kautsar bisa dilakukan dengan dua cara tersebut yakni dengan meningkatkan keterlibatan dalam aktivitas anak atau menanyakan secara langsung dan bisa dengan menanyakan kepada orang lain yaitu kepada anak asuh lain yang dekat dengan anak tersebut. Kontrol dan 
pemantauan yang optimal dari pengasuh bisa meningkatkan kedekatan antara anak dengan pengasuh, sehingga kualitas kelekatan anak dengan pengasuh juga meningkat.

Selain kebutuhan pada aspek kehangatan di atas, terdapat satu lagi kebutuhan yang dirasa harus dipenuhi yaitu kebutuhan adanya peningkatan pemahaman para pengasuh tentang bagaimana memberikan pengasuhan yang terbaik untuk anak-anak asuh, sesuai dengan standar nasional pengasuhan anak untuk LKSA. Tujuan dari peningkatan pemahaman dari pengasuh tentang bagaimana cara mengasuh, merawat dan mendidik anak adalah tercapainya kualitas kelekatan yang lebih baik. Peningkatan pemahaman dan penerapan SNPA yang dimaksud adalah bisa dengan memberikan pelatihan kepada para pengasuh tentang bagaimana memberikan pengasuhan agar tercipta kualitas kelekatan yang baik antara anak dengan pengasuh sebagai figur pengganti orangtua.

Selain analisis masalah serta kebutuhan, terdapat juga analisis sistem sumber yang dapat dimanfaatkan untuk upaya peningkatan. Berikut ini adalah uraian analisis sistem sumber yang dapat dimanfaatkan oleh anak maupun pengasuh untuk upaya peningkatan:

\section{Sumber Informal}

Sering juga disebut sumber alamiah, bantuan yang diberikan bisa berupa dukungan, nasehat serta kasih sayang dan lain sebagainya. Sumber informal tersebut yaitu: (a) orang tua kandung responden, sumber ini berlaku untuk responden yang masih mempunyai orang tua, baik yang masih lengkap, yatim atau piatu, (b) para pengasuh, (c) keluarga/ kerabat dekat responden, (d) pengurus LKSA Al Kautsar, (e) teman sekolah responden, dan (f) teman satu LKSA responden.

\section{Sumber Formal}

Sumber formal ini bersifat kelembagaan, yaitu berdasarkan keanggotaan dalam suatu lembaga. Sumber formal tersebut, yaitu: (a) Lembaga Kesejahteraan Sosial Anak (LKSA) Al Kautsar Lembang, (b) Yayasan Al Kautsar Indonesia yang menaungi LKSA Al Kautsar Lembang.

\section{Sumber Kemasyarakatan}

Sumber kemasyarakatan tersebut, yaitu Dinas Sosial Kabupaten Bandung Barat, yang di dalamnya juga terdapat pekerja sosial ataupun tenaga profesional 


\section{Kualitas Kelekatan Anak dengan Pengasuh \\ di Lembaga Kesejahteraan Sosial Anak (LKSA) \\ Al-Kautsar Lembang Kabupaten Bandung Barat}

- Mu'alimatus Sholihah, Denti Kardeti, dan Meiti Subardhini

lainnya serta program dan pelayanan lain untuk anak yatim, piatu, yatim piatu atau dhuafa dan anak terlantar lainnya yang dapat membantu memecahkan masalah.

\section{Kesimpulan}

Temuan dari penelitian di atas yang menunjukkan bahwa kualitas kelekatan antara anak dan pengasuh di LKSA Al-Kautsar dalam kategori sedang menunjukkan bahwa fungsi keberadaan LKSA itu masih belum sesuai dengan amanah yang diidealkan. Meskipun ini secara spesifik berkaitan dengan peranan dari LKSA, tetapi secara umum ini adalah tanggung jawab semua yakni pemerintah dan seluruh masyarakat. Dukungan dari semua pihak sangat dibutuhkan oleh pihak LKSA sebagai pelaku utama. Sedangkan pemerintah tentu merupakan pihak yang harus paling sigap dalam hal ini. Anak-anak adalah penerus masa depan. Pemerintah memiliki tanggung jawab untuk menunaikan amanah kemerdekaan yakni mencerdaskan anak-anak bangsa.

Selain membuka kesadaran tentang tanggung jawab semua pihak, penelitian ini juga memberikan kesimpulan penting tentang hal-hal yang melatarbelakangi persoalan kurangnya kualitas kelekatan anak dan pengasuh. Temuan ini memberi jalan kepada kita semua untuk mengambil solusi yang benar dengan mempertimbangkan poin-poin dari temuan penelitian ini. Dengan kata lain, temuan-temuan ini bisa menjadi rekomendasi bagi kebijakan yang bisa diambil oleh pemerintah dan semua pihak dalam kasus ini.

Salah satu yang diharapkan dari hasil penelitian ini adalah adanya langkah atau program untuk meningkatkan kualitas aspek kelekatan sehingga mencapai skor yang lebih tinggi. Program yang direkomendasikan adalah EDUFAS (Educating and Fun Sharing) "Peningkatan Kualitas Kelekatan Anak dengan Pengasuh di Lembaga Kesejahteraan Sosial Anak (LKSA) Al Kautsar Lembang Kabupaten Bandung Barat". Program yang direkomendasikan tersebut telah dianalisis kelayakannya dengan menggunakan metode analisis SWOT. Hasil dari analisis kelayakan program menunjukkan bahwa program tersebut dapat diimplementasikan untuk meningkatkan kualitas kelekatan anak asuh dengan pengasuh di LKSA Al-Kautsar Lembang Kabupaten Bandung Barat. Sehingga diharapkan tujuan-tujuan yang telah ditentukan sebelumnya dapat tercapai dengan maksimal.

Kemudian adapun saran yang dapat diusulkan oleh penulis adalah saran 
yang terdiri dari saran guna laksana dan saran penelitian selanjutnya untuk mengatasi permasalahan atau kekurangan pada penelitian yang telah dilakukan oleh penulis. Saran guna laksana atas LKSA Al-Kautsar meliputi: a) LKSA Al Kautsar diharapkan agar tetap konsisten dalam melaksanakan program yang sudah direkomendasikan dan terus melakukan inovasi-inovasi baru yang lebih kreatif dan juga lebih efekif dalam pelaksanaannya; b) LKSA Al Kautsar tetap memberikan arahan dan dukungannya kepada para pengasuh agar terus menjalin kedekatan dengan anak; c) LKSA Al Kautsar diharapkan dapat menjaga hubungan/relasi dan tetap melakukan koordinasi dengan berbagai pihak yang terkait; d) membenahi penerapan sistem pengasuhan agar lebih sesuai dengan Peraturan Menteri Sosial Republik Indonesia Nomor: 30/HUK/2011 tentang Standar Nasional Pengasuhan Anak (SNPA) untuk Lembaga Kesejahteraan Sosial Anak (LKSA); e) melakukan perekrutan sumber daya manusia (SDM) untuk pengasuh yang baru, mengingat masih kurangnya jumlah pengasuh yang ada di Lembaga Kesejahteraan Sosial Anak (LKSA) Al Kautsar Lembang.

Sedangkan bagi Dinas Sosial Kabupaten Bandung Barat: a) Dinas Sosial mengadakan kegiatan peningkatan kompetensi dari para pengasuh anak-anak di LKSA melalui kegiatan workshop atau seminar mengenai pengasuhan ataupun tema lain yang berhubungan dengan anak; b) memberikan dukungan terhadap program yang telah dilaksanakan dan memberikan stimulus kepada pihak Lembaga Kesejahteraan Sosial Anak (LKSA) Al Kautsar Lembang Kabupaten Bandung Barat, agar dapat memberikan inovasi-inovasinya dalam menciptakan kegiatan-kegiatan baru guna meningkatkan kualitas kelekatan diantara anakanak asuh dan pengasuh; c) melakukan peninjauan dan evaluasi secara rutin dan komprehensif kepada pihak Lembaga Kesejahteraan Sosial Anak (LKSA) Al Kautsar Lembang Kabupaten Bandung Barat; d) diharapkan Dinas Sosial Kabupaten Bandung Barat mampu meningkatkan koordinasi antar instansi pemerintahan lainnya seperti kepada Dinas Pengendalian Penduduk Keluarga Berencana Pemberdayaan Perempuan dan Perlindungan Anak (DP2KBP3A) Kabupaten Bandung Barat, Pusat Pelayanan Terpadu Pemberdayaan Perempuan dan Anak (P2TP2A) Kabupaten Bandung Baratatau bahkan Komisi Perlindungan Anak Indonesia (KPAI) dalam pelaksanaan program yang direkomendasikan ataupun program lain yang serupa.

Saran untuk penelitian selanjutnya: a) penelitian selanjutnya diharapkan dapat memperluas lingkup penelitian dengan cara melakukan penelitian dengan 
metode kualitatif untuk dapat menggali secara lebih mendalam bagaimana kualitas kelekatan antara anak dengan pengasuh; b) diharapkan dapat meneliti variable-variabel lain yang mungkin berhubungan dengan kualitas kelekatan anak dengan pengasuh; dan c) diharapkan dapat melakukan penelitian dengan topik yang serupa, namun pada karakteristik subjek yang berbeda, seperti halnya melakukan penelitian pada remaja karena merupakan masa peralihan dari masa kanak-kanak ke masa dewasa.

\section{Daftar Pustaka}

Huraerah, A. (2012). Kekerasan terhadap Anak. Bandung: Nuansa Cendekia. Badan Pusat Statistika Provinsi Jawa Barat. (2016). Data Jumlah Permasalahan Sosial Menurut Jenis. Retrived Agustus 2018. From https://jabar.bps.go.id/ statictable/2018/03/19/405/jumlah- permasalahan-sosial-menurutjenis-di-jawa-barat-2016.html

Bowlby, J. (1990). A Secure Base : Parent-Child Attachment and Healthy Human Development. U.S.A: Basic Books

Soetjiningsih, C.H. (2012). Perkembangan Anak: Sejak Pembuahan Sampai dengan Kanak-Kanak Akhir. Jakarta: Prenada Media Group.

Desmita. (2013). Psikologi Perkembangan. Cetakan VIII. Bandung: Remaja Rosdakarya.

Ervika, E. (2005). Jurnal Psikologi: Kelekatan (Attachment) pada Anak. Medan: Universitas Sumatera Utara.

Geldard, K. \& David, G. (2011). Konseling Remaja. Yogyakarta: Pustaka Pelajar. Oktyanti, I. (2017). Attachment Pengasuh dengan Anak Pra Sekolah. Jurnal UIN Sunan Ampel.

Suparno, P. (2001). Teori Perkembangan Kognitif John Piaget. Yogyakarta: Kanisius.

Peraturan Menteri Sosial Nomor 30 Tahun 2011 tentang Standar Nasional Pengasuhan Anak untuk Lembaga Kesejahteraan Sosial Anak

Profil Lembaga Kesejahteraan Sosial Anak (LKSA) Al Kautsar Lembang, Kabupaten Bandung Barat

Rodriguez, M.M.D., Melissa R. D., Susan L. C. (2009). Parenting Styles in a Cultural Context: Observations of "Protective Parenting" in First-Generation Latinos. From: https://search.proquest.com/sociology/docview/218874594/ 51885810FD3C4C0DPQ/1?accountid=50790 
Lestari, S. (2016). Psikologi Keluarga. Cetakan IV. Jakarta: Prenada Media Group. Undang-Undang Nomor 35 Tahun 2014 tentang Perubahan Atas UndangUndang Nomor 23 Tahun 2002 tentang Perlindungan Anak.

Efendi, Y. (2010). Psikologi Perkembangan Rentang Kehidupan. Bandung: PT. Remaja Rosdakarya. 